\title{
Reporting Challenges facing the Solomon Islands Ministry of Fisheries \& Marine Resources
}

\begin{abstract}
This study uses textual analysis of the audit reports of the Office of the Auditor General of Solomon Islands to determine the reporting compliance of the Solomon Islands Ministry of Fisheries \& Marine Resources (MFMR) for the period 2001 to 2013. The results of the study show that the MFMR faces considerable reporting challenges in the areas of internal control systems, recording and documentation. The study puts forward a number of ideas how the Ministry might meet these challenges to stem ongoing losses of fishing revenue for the national economy.
\end{abstract}

\section{Introduction}

There are considerable financial benefits to a Pacific Island economy if its national fisheries authority is able to comply with reporting regulations [1]. Sound financial reporting compliance facilitates the management of the entity's assets, liabilities, revenue and expenditure. It also offers a mechanism for interested parties to gather a sense of stewardship [2], governance [3], legitimacy [4] and accountability [5] of that authority. Moreover, it provides many stakeholders, such as coastal communities, regional fisheries agencies [6], and multilateral aid organisations, the opportunity to assess an authority's performance in terms of profitability, liquidity and efficiency [7].

The Solomon Islands Ministry of Fisheries and Marine Resources (MFMR) was created in 2006. Before it became a ministry, it operated as the Department of Fisheries and Marine Resources within the Ministry for Natural Resources. Under the Fisheries Act 1998, which repealed the Fisheries Act 1972, the MFMR was responsible for the administration of the fisheries of the Solomon Islands. Here, the Fisheries Act 1998 required the MFMR to manage and develop of fisheries in the Solomon Islands "for the benefit of the people of Solomon Islands" (Section 3(2)). In 2015, the Fisheries Act 1998 was repealed by the Fisheries Management Act 2015, which provided for the conservation, development, management and sustainable use of fisheries and marine resources, with a particular emphasis on the use of management plans (Section 17 and 18) and "accounts, records, return and documents" (Section 33(2)) related to fisheries and marine resources.

Financial reporting by Solomon Islands entities, including the national fishing authority, has an uncertain history [1]. The Ministry of Health and Medical Services, for example, in recent times has consistently found it difficult to produce accurate and timely annual reports because of challenges in applying asset management, bank reconciliations, internal controls and stock controls [8]. As with other fragile states, the Solomon Islands has experienced national disunity and civil society anxiety $[9,10]$, which may have disrupted efforts across many public sector entities to develop financial reporting in the country. However, these entities have recently received advice on financial reporting through the World Bank [11] and Regional Assistance Mission to Solomon Islands' State Owned Enterprises Accounts Strengthening Project [12], which in 2012 helped bring about the Solomon Islands first State Owned Enterprise unqualified audited financial report [13]. The need for sound MFMR financial reporting appears particularly pressing given that considerable parliamentary 
initiatives have been put in place to improve overall accountability in the Solomon Islands [4] and the MFMR supposedly

strives to provide an effective and efficient service to all stakeholders, promote interagency corporation and act as the focal point of national capacity building, research and development within the sector [14, p. 73].

The study poses the following research question: What challenges confront the Solomon Islands Ministry of Fisheries and Marine Resources in meeting its national legislative requirements for financial reporting? It is an important question because MFMR financial accounts may inform Solomon Island policy making on a number of issues of critical concern. If fishery revenue, fisheries resources, food security, stocktaking of fish, development of alternative fisheries income, fisheries management, fisheries administration and profitable fisheries development are seen as contemporary critical concerns for Solomon Islanders [15-28], then financial reporting with its emphasis on calculative rationalities has the means to help respond to these concerns by providing an account of both financial and non-financial operations of an entity's activities. It is particularly useful in providing an account of the status and outlook of complex ecosystems [29].

While the Solomon Islands has developed its own fisheries, it often does so in cooperation with foreign owners with problematic outcomes [30]. As with many other Pacific Island Countries, it has sought overseas partnerships for expertise and finance [7]. This has accelerated the intrusion of market systems and neoliberal consumerism into the traditional economy [23], which in turn has raised ideas of multilateral governance of fisheries [5], carbon revenue programmes [31], economic valuations of ecosystem services [32] and other social and environmental constructs that necessitate the generation of broad financial and non-financial reporting if an account of these activities are required. These neo-liberalist ideas, based on the precepts of classical modernization theory [33], have brought about unintended results for the Solomon Islands. Some "problematic and undesirable" social consequences have arisen, for example, from the interventionist approach of RAMSI, which has facilitated a neo-liberalist style of economic development through market mechanisms [34, p. 286].

\section{The Theory of Indigenous Alternatives}

The theory of indigenous alternatives provides space for local indigenous people to inform stakeholders about many of these issues at the local level [33]. Consistent with the idea of valuing traditional marine resource management [35-38] and the take-up alternative income opportunities at the community level [39], the theory emphasises the importance of local knowledge information in informing policy [40]. By embracing community, customary and traditional ways of governance, the theory of indigenous alternatives suggests that local management is able to respond to such matters as biodiversity and conservation [41], coastal ecosystem governance [3; 42], community-based fisheries management strategies [43-45], customary marine tenure arrangements [46-48] and traditionally-based influences on resource use [49-51]. There is also space within the tenets of the theory to give prominence to the voices of authoritative indigenous oversight bodies, such as the state auditor general and the PAC, to provide feedback on important matters of stewardship and accountability: 
indigenous economic logics shape contemporary economic practices and values in such a way as to reconfigure people's relationship with global capitalism to give it cultural meaning [52, p.119].

This is consistent with the notion of providing room for indigenous voices and counter-voices on local issues [53] that recognize indigenous values [54]. For example, in attempting to minimize environmental vulnerability and manage environmental hazards, indigenous knowledge of socio-ecological domains and major marine ecological habitat classification systems has helped inform Solomon Islands fishers on managing their marine habitat [55].

Indigenous knowledge is owned by local peoples, expressed in their native languages, and applied in the practice of their daily lives, which makes such traditional knowledge "indigenous" [56, p 351].

This knowledge allows indigenous people to adapt to changing circumstances [57], such as disasters to local marine ecosystems [58] and changing seascapes [59], and demonstrate local governance. Indigenous knowledge is not only used for the purposes of environmental management but also on other situated practices [60]. Thus, for example, the application of the theory of indigenous alternatives to financial reporting compliance helps developing countries critically reflect on their engagement with the reporting expectations of indigenousbased legislation [61].

\section{Methods}

Textual analysis uses textual evidence of archival information to interpret complex meanings of an issue [62].The interpretive analysis of the material evidence of text entails some limitations in that it "never fixes the complete meaning of the text because of the hidden, unrealized, and inexhaustible polysemy of text" [62, p. 795]. Nevertheless, textual analysis offers a qualitative method to probe for innovative insights [63], and to explore and understand an issue

that is both receptive to taken-for-granted, tacit understandings, and discriminating of privileged and peripheral contributions [64, p. 461]..

For example, it is relied upon by scholars to interpret the designs of policy instruments and the intentions of rulemaking $[63,65]$. Textual analysis is employed in this study to consider the challenges facing MFMR in meeting its financial reporting obligations, and is consistent with the methodological approach of previous explorative studies that examine the link between financial reporting and marine policy [66]. The formal analytic strategy of textual analysis as research technique commenced with the grounding of the research question, as posed earlier, and the identification of indigenous texts for analysis. These texts comprised the audit reports of the OAGSI that covered the MFMR's financial reporting for the yearsending 2002-2013 [67-73] to determine the compliance of MFMR financial reporting with indigenous legislative expectations of reporting.

In terms of the processes of the research technique, textual analysis followed very specific guidelines for formal analytic strategy [74]. By deconstructing and reconstructing text [75], textual analysis embraced traditional techniques of interpreting written data sources and 
processes to understand the subject matter [76] and to unfold meaning of events over time [77].

The framing of the indigenous expectations of reporting was constructed through the reporting compliance instruments of the Constitution of Solomon Islands, Public Finance and Audit Act 1996 (amended by Public Finance and Audit Act 2013), Financial Instructions and General Orders, and Fisheries Act 1998. After specifying the frames of analysis, themes from the instruments were then considered, providing a checklist of aggregated accounting reporting to reveal the MFMR's attention to reporting matters. Details of this checklist are provided in the second column of Table 1 and highlight the importance of documentation, internal controls and recording in the reporting process of MFMR. Each audit report was verified to determine if the procedures of audit and reporting were conducted.

\section{<Insert Table 1 here>}

Table 1 lists the indigenous financial reporting compliance instruments that frame the reporting expectations of the MFMR. The OAGSI is legally required to audit and examine accounts of MPMR under Section 108 of the Constitution of the Solomon Islands and Part VI of the Public Finance and Audit Act 1996 (as amended by Public Finance and Audit Act 2013). The Public Finance and Audit Act 1996 (as amended by Public Finance and Audit Act 2013) also requires the MFMR to present a statement of assets and liabilities, a statement of receipts and payments, a comparative statement of actual and estimated revenue, and a comparative statement of actual and estimated expenditure. The Finance Instructions and General Orders invoke six broad principles, including value for money; competitive purchasing; efficient, effective and ethical use of resources; accountability and transparency; financial sustainability; advancement of community equality and the provision of economic opportunities for Solomon Islanders. The Fisheries Act 1998 (amended by the Fisheries Management Act 2015) also requires the MFMR to manage and develop fisheries for all Solomon Islanders.

\section{Results}

No audit report on the Department of the Fisheries and Marine Resources was generated between years-ending 1987 and 2004, [67]. However, in an extensive audit report for yearending 2005, the OAGSI found that the Department of Fisheries and Marine Resources had not properly accounted for fishing income during years-ending 2001-2003, with "an estimated shortfall of $\$ 37.2$ million" [67, p. 1], in part because of a lack of accounting records:

Proper fishing licence records were not maintained and some important accounting records were deliberately destroyed which was a result of the breakdown of key controls [67, p. 4].

The OAGSI also found that there was a loss of fishing licence fees collected by the Department from locally based foreign fishing vessels and from bilateral agreements, where evidence of non-compliance with the Public Finance and Audit Act appeared to leave the Department "open to fraud and corruption" [67, p. 6]. 
As a result, the tracking of revenue received and due in the sector has been difficult, with large sums of money unaccounted for. There is no doubt that a significant amount of Fisheries revenue has been lost from the Government, which has had an impact on the economy $[67$, p. 6].

The OAGSI's year-ending 2006 audit report on MFMR briefly covered five financial years of audit from 2002 to 2006 [68], and noted that there was a

major revenue potential in the fisheries sector and identified an estimated shortfall in revenue of some $\$ 37$ million in three years [68, p. 14].

In the following year, the OAGSI found that the Department of Fisheries and Marine Resource's financial reports for year-ending 2007 were non-compliant with the Public Finance and Audit Act and Financial Instructions [69]. Here, the consequences of noncompliance were rendered in commercial and legal terms:

Breakdowns in procedures and practices as well as major deficiencies in internal controls have left the Department of Fisheries and Marine Resources open to fraud and corruption. Inadequate processes for collection of fishing licence fees resulted in major shortfalls in revenue $[69$, p. 10].

In the following year, the OAGSI investigated the administration and management of the newly-formed Ministry of Fisheries and Marine Resources and found matters of concern in relations to its fisheries projects, where small grants totalling \$6 million had been paid out. The OAGSI stated

that the management, monitoring and administration of project submissions for funding was poor [70, p. 107].

and revealed

many weaknesses which created the opportunity for fraud and misappropriation of SIG funds [70, p. 107].

It is worth pointing out here that in contrast to the relatively short space given in previous audit reports to explanations of Department shortfalls in reporting compliance, there is considerably more text written by the OAGSI to possible reasons for Ministry noncompliance:

The extent of breaches of normal procedure and the Financial Instructions suggests there was a deliberate act to circumvent the process for legal use of government moneys. The manner of distribution suggests political favouritism during a critical period of political uncertainty in the government, rather than consideration of the areas of greatest need in the Solomon Islands [70, p. 107].

In a marked change from its past audit reports, the OAGSI also provide relatively more details on the effect of this lack of reporting compliance on one of the MFMR's key stakeholder groups: 
A significant sum of money has been illegally expended and it is questionable whether the government will be able to exercise any control over the use of the moneys that were supposed to be for fisheries projects [70, p. 107].

In addition, the OAGSI found that the money allocated for fishing projects was supposed to be used to buy non-monetary assets such as canoes and equipment, rather than cash. These were then supposed to be distributed to successful applicants, with periodical checking for the proper use and care of the assets.

However it became quite clear that there was a lack of transparency and accountability in relation to the application and approval process for payment of these grants [70, p. 106].

The OAGSI also drew attention to "political favouritism" [70, p. 107] behind illegal expenditure, and the powerlessness of the government "to exercise any control over the use of the moneys that were supposed to be for fisheries projects" [70, p. 107]. In addition it disclosed in an audit of a $\$ 3.08$ million fisheries project that

There were many discrepancies in relation to this payment which breached normal payment procedures and the Financial Instructions which suggest there was a deliberate act to circumvent the process for the legal use of government moneys [70, p. 107].

While the OAGSI audit on MFMR's financial reports for year-ending 2009 was in the audit process of analysing the issues of imprests, procurement and expenditure, bank accounts and revenue [71, p.9], the OAGSI's audit on MFMR's financial reports for year-ending 2010 revealed missing documentation amounting to $\$ 225,537$ of the MFMR's special imprest account [72, p. 15], and missing documentation for payment vouchers worth $\$ 122,124$ [72, p. 17]. The OAGSI also disclosed that it was difficult to find supporting MFMR documentation for revenue collection and revenue analysis, which created the "risk of theft, misappropriation and unauthorized collection of public funds" [72, p. 18]. There was also "poor control over non-current assets" [72, p. 19], which opened up the risk of loss, misuse and theft of assets.

Critically, in terms of reporting challenges, the OAGSI also revealed that the MFMR did not maintain accounting records - such as licence files, receipt books and telegraphic transfers for revenue collection "of fishing licence and export permit revenue amounting to $\$ 21,819,095$ " [72, p. 18]. This meant that the OAGSI could not assess the accuracy and completeness of revenue collection. Further, the MFMR did not retire imprests amounting to $\$ 114,776$ in a timely manner [72], and missing special imprest documentation amounted to $\$ 255,537[72$, p. 15]. Moreover, the OAGSI discovered that MFMR did not charge interest revenue on unretired special imprests. Monthly bank reconciliations were also not performed by the MFMR and cash books were not maintained. These breaches in control increased

the risk of poor management, theft, fraud and misappropriation of public funds within the Ministry [72, p. 18].

The audit of the MFMR's financial reporting for year-ending 2012 again showed a "failure to retire special imprest accounts on a timely manner" [73, p. 33]. The MFMR failed to produce payment vouchers amounting in total to $\$ 2,386,016$ [73, p. 14]. Its bank reconciliations were not performed, and the asset register and a bank account details were not maintained. This 
"contributed to the Auditor General's decision to issue a disclaimer of opinion over the financial statements" [73, p. 33]. By year-ending 2014, no financial report for year-ending 2013 was furnished by the MFMR for audit inspection.

\section{Discussion}

Evidence-based textual analysis was used to ascertain the challenges facing the MFMR in meeting its financial reporting obligations but there are a number of limitations that need to be acknowledged in the study. First, great reliance is placed upon the indigenous authoritative voice of the OAGSI in terms of the reporting compliance of the MFMR. Although the study took into account MFMR management responses to the audit findings, there was no standalone narrative analysis conducted on management's viewpoints of reporting. Further research might conduct open-ended interviews to reveal managerial perspectives of the indigenous reporting expectations raised in the Solomon Islands. Second, the study did not extend to the viewpoints of other key stakeholders of the MFMR, particularly those groups residing in rural and coastal communities that rely upon the reporting compliance of the MFMR. Again, further research might consider how Solomon Islanders respond to the issue of reporting (non-)compliance by their national fishing authority and whether the information imparted through the annual report is considered important for decision-making at the community level. This is particularly important given that a guiding principle of the Financial Instructions is that reporting aids in advancing community equality and providing economic opportunities for Solomon Islanders.

There is clear evidence from the results of the study that the MFMR was challenged by the reporting expectations placed upon it by the Public Finance and Audit Act 1996. The OAGSI found there were major shortfalls in MFMR revenue collection and considerable MFMR internal control deficiencies. The results of the analysis showed that the MPMR was troubled by the safeguarding of the collection and custody of revenue. Disbursing revenue for the purposes it was given also appeared to cause difficulties for the MPMR. The OAGSI's findings of MFMR mismanagement and poor monitoring of funding suggests MPMR expenditure was incurred without regard to economy and avoidance of waste. It was also noticeable that the timeliness of submission of Department and Ministry financial reports for audit did not comply with the Public Finance and Audit Act 1996.

The discovery by the OAGSI of MFMR's non-compliance with the expectations of the Financial Instruments over the 13 year sample period suggests there was evidence of fraud, misappropriation of funds and loss of control of funds. The Financial Instruments' guiding principles of transparency and accountability were clearly compromised by missing documentation, a lack of records and mismanagement of internal controls. The lack of completion of bank reconciliations and the non-maintenance of asset registers added to the difficulties of liquid and non-liquid asset management. Further, there appeared evidence from the results that the fundamental principles of value for money and financial sustainability invoked by the Financial Instruments were given short shrift by the MFMR. There also did not appear to be an efficient, effective and ethical use of MFMR resources.

The results of the study may interest the market-bound foreign interventionist approaches of the World Bank and RAMSI. There appears to be a need for local take-up of the most rudimentary forms of bookkeeping procedures - asset management, bank reconciliations, internal controls and documentation - before MFMR is in a position to prepare reports to a 
readership interested in wide-ranging social and environmental accounts of the status and outlook of its complex ecosystem. It is difficult to provide calculations of carbon revenue programmes and economic valuations of ecosystem services if financial statements are inaccurate or incomplete.

\section{Conclusion}

The Fisheries Act 1998 (amended by the Fisheries Management Act 2015) requires the MFMR to manage and develop fisheries for the benefit of Solomon Islanders. One way to bring about this benefit to Solomon Islanders is for the MFMR to improve its compliance with indigenous legislative reporting compliance instruments. It could do this in a number of ways. First, indigenous oversight bodies such as the OAGSI and PAC could provide further feedback to the MFMR on how it could comply with specific parts of the Financial Instructions, particularly in the areas of asset management and revenue collection. Textual analysis revealed that while the OAGSI was able to provide evidence of non-compliance, there appeared an opportunity for this independent body to extend its expertise to demonstrate how MFMR could introduce further processes to provide unqualified timely annual financial reports. In keeping with the tenets of the theory of indigenous alternatives, advice from these indigenous authoritative voices may guide MFMR management in culturally and socially acceptable ways.

There is also an opportunity for the PAC to provide a more detailed response to the OAGSI's audit's reports when they are tabled to parliament. In relation to the OAGSI's audit on MFMR's year-ending 2012 financial statements which was tabled to parliament, the PAC did not directly refer to the matters raised by the OAGSI. Rather, it was more concerned with the lack of data provided by MFMR on offshore long fishing, the overstretching of MFMR's staffing resources, and the passing of legislation needed for the continuing export of onshore processed fish to the European Union [14].

A guiding principle of the Financial Instruments is for reporting to advance community equality and provide economic opportunities for Solomon Islanders. Given a central tenet of the theory of indigenous alternatives is to inform policy making at the local level, a further indigenous alternative for the improvement of MFMR reporting compliance may be found in encouraging MFMR management to communicate oral or written summaries of accurate annual financial statements to outer (rural and coastal) communities, where the vast majority of Solomon Islanders live. In this way, the relevance of compliance to the MFMR as preparers of financial reports may be enhanced given that community-based fisheries as users of financial reporting rely upon the successful collection and disbursement of revenue by the MFMR. Answering to active user-groups such OAGSI, PAC as well as community-based fisheries may motivate MFMR management to improve its reporting compliance to fulfil culturally acceptable and financially strengthening ways of accountability.

Another relatively inexpensive alternative means of improving MFMR financial reporting compliance is to call upon MFMR managers to make links with local indigenous accounting groups such as the Institute of Solomon Islands Accountants. Although the accounting sector is small in the Solomon Islands, the take-up of local indigenous expertise on reporting matters appears a sensible one given the Institute's familiarity with the local public sector reporting context. The PAC acknowledges the concern about overstretched MFMR staff resources but it appears there may also be scope for the Solomon Islands government to increase resources for the OAGSI, given the increasing operational activities of the MFMR. 
The great strength of using some of these indigenous alternatives for the improvement of reporting compliance is that both technical and cultural embedded understandings of reporting are taken into account at the local level.

An additional strength is that it that it offers a counter-voice to the foreign interventionist approach of the RAMSI with its liberal mode of economic development by using local agency rather than foreign advice in tackling its reporting challenges. Further research might consider how the strengthening of reporting of MFMR may arise from the help of outside agencies that are prepared to develop reporting through greater attention to local level matters

\section{References}

[1] Hanich Q, Tsamenyi M. Managing fisheries and corruption in the Pacific Islands region. MarPolicy 2009;33:386-392.

[2] Duggan DE, Kochen M. Small in scale but big in potential: Opportunities and challenges for fisheries certification of Indonesian small-scale tuna fisheries. Mar Policy 2016;67:30-39.

[3] Cohen PJ, Evans LS, MillsM. Social networks supporting governance of coastal ecosystems in Solomon Islands. Conserv Lett 2012;5:376-86.

[4] Clark C, Levy K. Improving Accountability in the Solomon Islands: A Review of Auditor-General Enabling Legislation Asia Pac Law Rev, 2012;20:45-62.

[5] Chand S, Grafton RQ, Petersen EH. Multilateral governance of fisheries: management and cooperation in the western and central Pacific tuna fisheries. Mar Resourc Econ, 2003; $18: 329-344$.

[6] Barclay K. Impacts of tuna industries on coastal communities in Pacific Island countries, Mar Policy 2010;34:406-413.

[7] Parris H. Tuna dreams and tuna realities: Defining the term "maximising economic returns from the tuna fisheries"' in six Pacific Island states. MarPolicy 34 (2010) 105-113.

[8] Brown AM. Auditing Solomon Islands' Health and Medical Governance. Clinical Governance: an International Journal 2013;8:1-10.

[9] Nanau GL. Solomon Islands. Contemp Pacific 2015;27;528-537.

[10] Nanau GL. Solomon Islands. Contemp Pacific. 2014;26:516-523.

[11] World Bank. Doing Business 2015: Going Beyond Efficiency. Washington DC, World Bank. 2014.

[12] Hameiri S. State building or crisis management? A critical analysis of the social and political implications of the Regional Assistance Mission to Solomon Islands.

Third World Q, 2009:30 35-52. 
[13] SIEA. Solomon Islands Electricity Authority Annual Report 2013. Solomon Islands Electricity Authority (SIEA). Honiara, Solomon Islands. 2014.

[14] PAC. Report on the 2015 Appropriation Bill 2015, NP-Paper no. 5/2015, Presented on $8^{\text {th }}$ April 2015, Parliamentary Account Committee (PAC). National Parliament Office. Honiara, Solomon Islands. 2015.

[15] Brewer TD, Cinner JE, Green A, Pandolfi JM. Thresholds and multiple scale interaction of environment, resource use, and market proximity on reef fishery resources in the Solomon Islands. Biol Conserv 2009;142:1797-807.

[16] Bell JD, Allain V, Allison EH, Andréfouët S, Andrew NL, Batty MJ, Blanc M, Dambacher JM, Hampton J, Hanich Q, Harley S, Lorrain A, McCoy M, McTurk N, Nicol S, Pilling G, Point D, Sharp MK, Vivili P, Williams P. Diversifying the use of tuna to improve food security and public health in Pacific Island countries and territories, Mar Policy 2015;51:584-591.

[17] Cleasby N, Schwarz A, Phillips M, Paul C, Pant J, Oeta J, Pickering T, Meloty A, Laumani M, Kori M. The socio-economic context for improving food security through land based aquaculture in Solomon Islands: A peri-urban case study. Mar Policy 2014;45:89-97.

[18] Albert JA, Beare D, Schwarz A-M, Albert S, Warren R, et al. (2014) The Contribution of Nearshore Fish Aggregating Devices (FADs) to Food Security and Livelihoods in Solomon Islands. PLoS ONE 9(12): e115386. doi:10.1371/journal.pone.0115386.

[19] Bell JD, Albert J, Andréfouët S, Andrew N, Blanc M, Bright P, Brogan D, Campbell B, Govan H, Hampton J, Hanich Q, Harley, Jorari A, Smith ML, Pontifex S, Sharp MK, Sokimi $\mathrm{W}$, Webb A. Optimising the use of near shore fish aggregating devices for food security in the Pacific Islands. Mar Policy 2015;56:98-105.

[20] Bell JD, Kronen M, Vunisea A, Nash WJ, Keeble G, Demmke A, et al. Planning the use of fish for food security in the pacific. Mar Policy 2009;33:64-76.

[21] Hunt C. Economic globalisation impacts on Pacific marine resources. Mar Policy 2003;27:79-85.

[22] Kronen M, Vunisea A, Magron F, McArdle B Socio-economic drivers and indicators for artisanal coastal fisheries in Pacific island countries and territories and their use for fisheries management strategies. MarPolicy 2010;34:1135-1143.

[23] Brewer TD, Moon K. Towards a functional typology of small-scale fisheries comanagement informed by stakeholder perceptions: A coral reef case study. Mar Policy 2015;51:48-56.

[24] Parsons ECM, Rose NA, Telecky TM, The trade in live Indo-Pacific bottlenose dolphins from Solomon Islands - A CITES decision implementation case study. Mar Policy 2010;34:384-388. 
[25] Omata Y, Hammond T, Itoh K, Murata K. Antibodies against Toxoplasma gondii in the Pacific bottlenose dolphin (Tursiops aduncus) from the Solomon Islands. J Parasitol 2005;91:965-967.

[26]Tachibana M, Watanabe K, Kim S, Omata Y, Murata K, Hammond T, et al. Antibodies to Brucella spp. In Pacific bottlenose dolphins from the Solomon Islands. J Wildlife Dis 2006;42:412-4.

[27] Shanks S. Introducing a transferable fishing day management regime for Pacific Island countries. Mar Policy 2010;34:988-994.

[28] Hanich Q, Teo F, Tsamenyi M. A collective approach to Pacific islands fisheries management: Moving beyond regional agreements. Mar Policy 2010;34:85-91.

[29] Dobbs K, Day J, Skeat H, Baldwin J, Molloy F, McCook L, Johnson M, Ellito B, Skeat A, Vohland K, Wachenfeld D, Kenchington R. Developing a long-term outlook for the Great Barrier Reef, Australia: A framework for adaptive management reporting underpinning an ecosystem-based management approach. Mar Policy 2011;35:233-240.

[30] Hannesson R. The exclusive economic zone and economic development in the Pacific island countries. Mar Policy 2008;32:886-897.

[31]Warren-Rhodes K, Schwarz A-M., Boyle LN, Albert J, Agalo SS, Warren R, et al.,Mangrove ecosystem services and the potential for carbon revenue programmes in Solomon Islands. Environ Conserv 2011;38:485-496.

[32] Laurans Y, Pascal N, Binet T, Brander L, Clua E, G.David, et al.,Economic valuation of ecosystem services from coral reefs in the South Pacific: taking stock of recent experience. J Environ Manag 2013;116:135-144.

[33] Curry GN. Moving beyond postdevelopment: Facilitating indigenous alternatives for development. Econ Geogr 2003;79:405-423.

[34] Droogan J, Waldek, L. Continuing drivers of violence in Honiara: making friends and influencing people. Aust J Int Aff 2015:69:285-304.

[35] Sunderlin WD. Beyond Malthusian overfishing: the importance of structural and nondemographic factors. SPC Traditional Marine Resource Management and Knowledge Information Bulletin 1994;4:2-6.

[36] Grant KL, Miller ML. A cultural consensus analysis of marine ecological knowledge in the Solomon Islands. SPC Tradit Mar Resour Manag Knowl Inf Bull 2004;17:3-13.

[37] Hamilton RJ, Giningele M, Aswani S, Ecochard JL. Fishing in the dark-local knowledge, night spearfishing and spawning aggregations in the Western Solomon Islands. Biol Conserv 2012;1:246-25

[38] Brewer TD. Dominant discourses, among fishers and middlemen, of the factors affecting coral reef fish distributions in Solomon Islands. Mar Policy 2013;37:245-53. 
[39] Kronen M, Magron F,McArdle B,Vunisea A. Reef finfishing pressure risk model for Pacific Island countries and territories. Fish Res 2010;101(1):1-10.

[40] Gegeo DW Watson-Gegeo KA. Whose Knowledge? Epistemological Collisions in Solomon Islands Community Development. Contemp Pacific 2002;14:377-409.

[41] Boseto D, Morrison C, Pikacha P, PitakiaT.Biodiversity and conservation of freshwater fishes in selected rivers on Choiseul Island, Solomon Islands. South Pac JN at Appl Sci 2008;25(1):16-21.

[42] Knauft BM. Gender identity, political economy and modernity in Melanesia and Amazonia. J R Anthropol Inst 1997;3:233-259.

[43] Crean K. Centralised and community-based fisheries management strategies: case studies from two fisheries dependent archipelagos. Mar Policy 1999;23:243-257.

[44] Abernethy KE, Bodin O, Olsson P, Hilly Z, Schwarz A-M. Two steps forward, two steps back: the role of innovation in transforming towards community-based marine resource management in Solomon Islands. Global Environ Change 2014;28:309-21.

[45] Ruddle K.The context of policy design for existing community-based fisheries management systems in the Pacific Islands. Ocean Coast Manage 1998;40:105-26.

[46] Foale S, Cohen P, Januchowski-Hartley S, Wenger A, Macintyre M. Tenure and taboos: origins and implications for fisheries in the Pacific. Fish Fish 2010;12: 357-369

[47] Cinner JE, Aswani S. Integrating customary management into marine conservation. Biol Conserv 2007;140:201-216.

[48] Aswani S, Hamilton RJ. Integrating indigenous ecological knowledge and customary sea tenure with marine and social science for conservation of bumphead parrotfish (Bolbometopon muricatum) in the Roviana Lagoon, Solomon Islands. Environ Conserv 2004;31:69-83.

[49] Cinner JE, Marnane MJ, McClanahan TR, Clark TH, Ben J. Trade, tenure, and tradition: influence of sociocultural factors on resource use in Melanesia, Conserv Biol 2005;19:14601477.

[50] Hviding E, Baines G, Community-based BK. Fisheries management, tradition and the challenges of development in Marovo. Solomon Islands. Dev Change 1994;25:13-39.

[51] Johannes RE. Traditional marine conservation methods in Oceania and their demise. Annu Rev Ecol Syst 1978;9:349-364.

[52] Curry G, Koczberski G, Connell J. Introduction: enacting modernity in the Pacific? Aust Geogr 2013;43:115-125. 
[53] Gegeo DW, Watson-Gegeo K. Adult Education, Language Change, and Issues of Identity and Authenticity in Kwara'ae (Solomon Islands). Anthropol Educ Quart 1999;30:2236.

[54] Walter RK, Hamilton RJ. A cultural landscape approach to community-based conservation in Solomon Islands. Ecol Soc 2014;19:41 http://dx.doi.org/10.5751/ES-07105190445

[55] Lauer M, Matera J. Who Detects Ecological Change After Catastrophic Events? Indigenous Knowledge, Social Networks, and Situated Practices. Hum Ecol 2016;44(1):3346.

[56] Hunn ES, Meilleur BA. Commentary on "Indigenous Ecological Knowledge as Situated Practices: Understanding Fishers' Knowledge in the Western Solomon Islands" by Matthew Lauer and Shankar Aswani. Am Anthropol 2010;112:351-351.

[57] Lauer M, Aswani S. Indigenous Knowledge and Long-term Ecological Change: Detection, Interpretation, and Responses to Changing Ecological Conditions in Pacific Island Communities. Environ Manage, 2010;45:985-997.

[58] Lauer M. Oral Traditions or Situated Practices? Understanding how Indigenous Communities Respond to Environmental Disasters. Hum Organ 2012;71:176-187.

[59] Aswani S, Lauer M. Indigenous people's Detection of Rapid Ecological Change. Conserv Biol 2014;28:820-828.

[60] Lauer M, Aswani S. Indigenous Ecological Knowledge as Situated Practices: Understanding Fishers' Knowledge in the Western Solomon Islands Am Anthropol 2009;111:317-329.

[61] Brown AM. The Need for Improved Financial Reporting of a Developing Country Energy Utility, Renew Sust Energ Rev 2016;59:1448-1454.

[62] Lejano RP, Leong C. A Hermeneutic Approach to Explaining and Understanding Public Controversies, JPART 2012;22:793-814.

[63] Bevir M, Richards D. Decentring Policy Networks: Lessons and Prospects, Public Admin 2009;87:132-141.

[64] Elston, T. Not So 'Arm's Length': Reinterpreting Agencies in UK Central Government, Public Admin 2014;92:458-476.

[65] Chan HS, Gao, J. Can the Same Key Open Different Locks? Administrative Values Underlying Performance Measurement in China, Public Admin 2013 91:366-380. 
[66] Brown AM. Reporting Compliance of National Fisheries Authority of Papua New Guinea. Mar Policy 2015;51:196-201

[67] OAGSI. Special audit report into the Financial Affairs of the Department of Fisheries and Marine Resources. Honiara: Prepared by the Office of the Auditor General for the Solomon Islands Government - National Parliament Paper No.9, Honiara, Solomon Islands. 2005.

[68] OAGSI. Office of the Auditor General Annual Reports 2002-2006. Office of the Auditor General of Solomon Islands (OAGSI). Honiara, Solomon Islands. 2006.

[69] OAGSI. An Auditor-General's Insights into Corruption in Solomon Islands Government, National Parliament Paper No. 48 of 2007. Office of the Auditor General of Solomon Islands (OAGSI). Honiara, Solomon Islands. 2007.

[70] OAGSI. Status of Audits of Solomon Islands Government Entities as at 30 June 2008, National Parliament Paper No. 18 of 2008. Office of the Auditor General of Solomon Islands (OAGSI). Honiara, Solomon Islands. 2008.

[71] OAGSI. Annual Report of the Auditor General 2010. National Parliament Paper No. 18 of 2011. Office of the Auditor General of Solomon Islands (OAGSI). Honiara, Solomon Islands. 2011.

[72] OAGSI. Annual Report of the Auditor General 2011. National Parliament Paper No. 23 of 2012. Office of the Auditor General of Solomon Islands (OAGSI). Honiara, Solomon Islands. 2012.

[73] OAGSI. Annual Report of the Auditor General 2014 covering 2012 and 2013 operations. National Parliament Pape No. 1 of 2014. Office of the Auditor General of Solomon Islands (OAGSI). Honiara, Solomon Islands. 2014.

[74] Iannantuono A, Eyles A. Meanings in Policy: A Textual Analysis of Canada's ‘Achieving Health For All' Document. Soc Sci Med 1997;44:1611-1621.

[75] Jones J, Shanks A. Laid Bare: Religious Intolerance Within Online Commentary about 'Bare Below the Elbows' Guidance in Professional Journals. Health Care Anal 2013;21:271281.

[76] Zanasi M, Calisti F, Di Lorenzo G, Valerio G, Siracusano A. Oneiric Activity in Schizophrenia: Textual Analysis of Dream Reports. Conscious Cogn 2011;20:337-348.

[77] Gill D, Griffin A. Good Medical Practice: What Are We Trying to Say? Textual Analysis Using Tag Clouds. Med Educ 2010;44:316-322. 